\title{
Physical properties and quality traits of meat in two conservative flocks of ducks*
}

\author{
T. Kisiel and J. Książkiewicz ${ }^{1}$ \\ Research Institute of Animal Production, Department of Waterfowl Breeding \\ Dworzyska, 62-035 Kórnik, Poland
}

(Received 1 September 2003; accepted 14 January 2004)

\begin{abstract}
In eviscerated carcasses of ducks from Khaki Campbell (Kh1) and Pekin (P8) conservative flocks, percentages of breast muscles, leg muscles, skin with subcutaneous fat and abdominal fat, as well as meat quality traits $\left(\mathrm{pH}_{15}, \mathrm{pH}_{24}\right.$ and colour) and muscle fibre microstructure were determined. Statistically significant differences were detected in body weights at 7 weeks of age (1383 and $2292 \mathrm{~g}$ in Kh1 and P8 males, 1396 and $2177 \mathrm{~g}$ in Kh1 and P8 females, respectively).

$\mathrm{pH}_{15}$ values of breast and leg muscles of $\mathrm{Kh} 1$ and $\mathrm{P} 8$ ducks were higher than $\mathrm{pH}_{24}$ values of these muscles. Meat of ducks from both flocks showed lower $\mathrm{pH}_{15}$ and $\mathrm{pH}_{24}$ values in breast muscles (from 6.07 to 6.52 and from 5.84 to 6.14) compared to leg muscles (from 6.27 to 6.60 and from 6.15 to 6.38 , respectively). Birds from both flocks were characterized by a similar colour of breast muscle (L) - 46.90 and 44.01 in Kh1 males and females; 44.69 and 44.34 in P8 males and females, respectively. Breast muscles of Kh1 birds of both sexes were characterized by a significantly greater yellowness (b) compared to the muscles of P8 ducks. In Pectoralis superficialis muscle of ducks of both flocks, the diameters of white $(\alpha \mathrm{W})$ and red fibres $(\beta \mathrm{R})$ were lower than in Biceps femoris muscle. Muscle fibres of Kh1 compared to P8 ducks were characterized by lower $\beta \mathrm{R}$ and $\alpha \mathrm{W}$ fibre diameters in Pectoralis superficialis (31.3 and $16.6 \mu \mathrm{m}$ ) and Biceps femoris muscles (46.0 and $32.7 \mu \mathrm{m}$, respectively).
\end{abstract}

KEY WORDS : ducks, biodiversity, tissue composition, meat quality

\section{INTRODUCTION}

The duck biodiversity conservation programme in Poland includes genetic reserve and conservative flocks (Poland's Country Report on Farm Animal Genetic Resources, 2002). It follows current international trends in methods of managing

\footnotetext{
* Supported by the State Committee for Scientific Research, Grant No. 3 PO6Z 00422

${ }^{1}$ Corresponding author: e-mail: ksiaz@poczta.onet.pl
} 
such flocks (Fujihara and Xi, 1999). Previous studies have described national duck populations in terms of reproductive and meat traits (Książkiewicz, 1997, 2002) and taken a dynamic view of changes in reproductive traits over 8 generations (Książkiewicz and Kiełczewski, 1998) or in meat traits over 10 generations of conservative ducks (Książkiewicz, 2002). In Polish Pekin (P33) and Miniducks (K2) differences were shown for chemical composition of meat (Wołoszyn et al., 2002), while Książkiewicz et al. (1999) confirmed the influence of bird origin on physical properties and quality traits of eggs. Growth curves of Khaki Campbell (Kh1) and Pekin (P8) ducks, fitted with the Gompertz function, showed differences in growth rates, which in turn may affect meat quality traits (Książkiewicz et al., 1997). From the consumer's point of view, the evaluation of meat quality is strongly influenced by traits such as muscle colour, muscle $\mathrm{pH}$, and muscle fibre microstructure. However, this type of studies has never been conducted in conservative flocks of ducks. Earlier studies only dealt with a single synthetic group of multipurpose type and A44 ducks (Kłosowska and Bernacki, 1999). These reasons have prompted us to investigate the microstructure and quality traits of muscles of Kh1 and P8 ducks.

Previous studies comparing various conservative flocks of ducks have revealed that the analysed populations represented different utility types, i.e. the light type (Kh1) and the general-purpose type (P8), with the birds' body weights and performance being the principal criteria for classification (Książkiewicz, 1995).

The objective of this study was to investigate 7-week-old Khaki Campbell light ducks and Pekin multipurpose type of ducks from conservative flocks for selected physical properties and quality traits of meat. It would enriche understanding of biodiversity and improve breeding of duck simultaneously giving opportunity to improve breeded populations.

\section{MATERIAL AND METHODS}

The experiment involved ducks from conservative flocks kept in situ at the Department of Waterfowl Breeding Dworzyska, belonging to the Research Institute of Animal Production in Kraków (Poland): Jansen

- Khaki Campbell (Kh1) ducks imported in 1978 from a French company

- Pekin ducks of Danish origin (P8) imported in 1978 from Danish Poultry Houses.

Until 7 weeks of age, ducks were kept in a typical windowless poultry house with no access to the outside yard. The housing system was in accordance with the rules of duck raising (Książkiewicz, 2003). Each flock comprised 60 birds (30 males and 30 females). Ducks were allowed ad libitum access to complete feed 
formulated for 1 to 3 and 4 to 7 weeks of age. Chemical composition of the feed is shown in Table 1 .

TABLE 1

Composition of the feed mixtures, $\mathrm{g} / \mathrm{kg}$

\begin{tabular}{lcc}
\hline Components & Complete diets for ducks - weeks of age \\
& 1 to 3 & 4 to 7 \\
\hline Dry matter & 899.2 & 901.9 \\
Crude protein & 183.0 & 178.5 \\
N-free extractives & 559.7 & 556.6 \\
Crude fat & 41.4 & 38.5 \\
Crude fibre & 23.7 & 23.3 \\
Crude ash & 91.4 & 105.0 \\
ME, MJ/kg & 11.83 & 11.15 \\
& & \\
Amino acids & & \\
$\quad$ lysine & 7.4 & 6.9 \\
$\quad$ methionine & 4.0 & 3.1 \\
methionine + cystine & 5.9 & 6.6 \\
threonine & 5.6 & 5.6 \\
\hline
\end{tabular}

All birds were weighed at 7 weeks of age. Based on average body weights of drakes and ducks, 6 males and 6 females were chosen from each flock. For $12 \mathrm{~h}$ before slaughter, the birds were only allowed access to water. After slaughter, ducks were plucked and eviscerated, the carcasses were chilled for $24 \mathrm{~h}$ at $4^{\circ} \mathrm{C}$. Next the carcasses were dissected into breast muscles, thigh and lower thigh muscles, skin with subcutaneous fat and abdominal fat, all parts were weighed.

$\mathrm{pH}$ values of breast muscles and leg muscles were measured 15 min post mortem $\left(\mathrm{pH}_{15}\right)$ and after 24-h chilling $\left(\mathrm{pH}_{24}\right)$ with a glass electrode connected with a Cyberscan $\mathrm{pH}$ meter. Pectoralis superficialis muscle colour was evaluated with a colorimeter (Chroma Meter CR 310, Minolta) using the Hunter colour scale L, a, b. L was assumed to be a lightness variable on a scale from 0 for an ideal black to 100 for an ideal white, a represented the degree of redness (if positive) or greenness (if negative), and $b$ represented the degree of yellowness (if positive) or blueness (if negative) (Wołoszyn, 2002).

Fibre microstructure was analysed with Pectoralis superficialis and Biceps femoris muscles obtained from Kh1 and P8 females. After the ducks were slaughtered and exsanguinated, sections of muscles were taken and frozen in liquid nitrogen at $-196^{\circ} \mathrm{C}$. Slices of $10-\mu \mathrm{m}$ thickness were cut using a cryostat. To distinguish two types of muscle fibres - light blue and dark blue according to Dubowitz et al. (1973) or white $(\alpha \mathrm{W})$ and red ( $\beta \mathrm{R})$ according to Ashmore and Doerr (1971) - reactions for the activity of succinate dehydrogenase were performed. The specimens 
were evaluated under a microscope at $150 \times$ magnification to determine dimensions of the smallest diameters for 200 fibres (both $\alpha \mathrm{W}$ and $\beta \mathrm{R}$ ) following the Brooke method (1970). Cross-sections of Pectoralis superficialis and Biceps femoris muscles were printed out using a microscopic image analysis system (Leica Q500 MC) after previously placing each randomly selected specimen under an optical microscope (Nicon).

The numerical data for carcass components and meat quality were analysed statistically (mean, SEM) by 2-way analysis of variance, i.e. for flock, and for sex. Moreover fibre diameters were compared by 1-way analysis of variance i.e. for flock. The results were processed with the ANOVA, and the significance of differences between groups was statistically verified by the Student $t$ - test (Kobus et al., 2001).

\section{RESULTS}

In 7-week-old Kh1 birds, no sexual dimorphism was detected for body size, while P8 drakes were characterized by a significantly greater body weight compared to ducks (Table 2). Females compared to males of both groups were characterized by a significantly higher dressing percentage, greater proportions of breast muscles, skin with subcutaneous fat and abdominal fat, and a lower proportion of leg muscles in their carcasses.

TABLE 2

Comparison of mean values for body weight, dressing percentage and content of some carcass tissue components in two conservative flocks of ducks aged 7 weeks

\begin{tabular}{|c|c|c|c|c|c|c|c|c|}
\hline \multirow[b]{2}{*}{ Flock } & \multirow[b]{2}{*}{ Sex } & & \multirow[b]{2}{*}{$\begin{array}{l}\text { Body } \\
\text { weight } \\
\text { g }\end{array}$} & \multirow[b]{2}{*}{$\begin{array}{c}\text { Dressing } \\
\%\end{array}$} & \multicolumn{4}{|c|}{ Percentage in eviscerated carcass with neck, \% } \\
\hline & & & & & $\begin{array}{c}\text { breast } \\
\text { muscles }\end{array}$ & $\begin{array}{c}\text { leg } \\
\text { muscles }\end{array}$ & $\begin{array}{c}\text { skin with } \\
\text { subcutane-ous } \\
\text { tissue }\end{array}$ & $\begin{array}{c}\text { abdominal } \\
\text { fat }\end{array}$ \\
\hline \multirow{4}{*}{ Kh1 } & \multirow{2}{*}{ 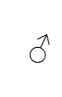 } & $\mathrm{x}$ & $1383^{\mathrm{b}}$ & $65.7 * \mathrm{~b}$ & $7.9 * a$ & $16.9^{* a}$ & $25.8 * \mathrm{~b}$ & $1.1 * \mathrm{~b}$ \\
\hline & & SEM & 6.4 & 0.5 & 0.3 & 0.5 & 0.5 & 0.1 \\
\hline & \multirow{2}{*}{ q } & $\mathrm{x}$ & $1396^{\mathrm{b}}$ & $68.4^{\mathrm{b}}$ & $9.7^{\mathrm{a}}$ & $14.9^{\mathrm{a}}$ & $28.1^{\mathrm{a}}$ & $1.7^{\mathrm{a}}$ \\
\hline & & SEM & 14.8 & 0.2 & 0.3 & 0.3 & 0.4 & 0.3 \\
\hline \multirow{4}{*}{ P8 } & \multirow{2}{*}{ 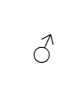 } & $\mathrm{x}$ & $2292 * a$ & $69.2 * a$ & $10.0^{\mathrm{a}}$ & $14.2^{\mathrm{b}}$ & $28.9^{\mathrm{a}}$ & $1.9^{\mathrm{a}}$ \\
\hline & & SEM & 23.7 & 0.4 & 0.6 & 0.6 & 0.7 & 0.2 \\
\hline & \multirow{2}{*}{ q } & $\mathrm{x}$ & $2177^{\mathrm{a}}$ & $70.5^{\mathrm{a}}$ & $10.3^{\mathrm{a}}$ & $13.7^{\mathrm{a}}$ & $29.1^{\mathrm{a}}$ & $2.0^{\mathrm{a}}$ \\
\hline & & SEM & 19.1 & 0.4 & 0.5 & 0.3 & 0.9 & 0.2 \\
\hline
\end{tabular}

* values between males and females in flock differ significantly

values in columns marked with different letters differ significantly $(\mathrm{P} \leq 0.05)$ 
TABLE 3

Comparison of meat quality traits in 7-week-old ducks from two conservative flocks

\begin{tabular}{|c|c|c|c|c|c|c|c|c|c|}
\hline \multirow[t]{2}{*}{ Flock } & \multirow[t]{2}{*}{ Sex } & & \multicolumn{2}{|c|}{$\begin{array}{c}\mathrm{pH} \text { of breast } \\
\text { muscles }\end{array}$} & \multicolumn{2}{|c|}{$\mathrm{pH}$ of leg muscles } & \multicolumn{3}{|c|}{$\begin{array}{l}\text { Breast muscle colour on the } \\
\text { Hunter scale }\end{array}$} \\
\hline & & & $15 \mathrm{~min}$ & $24 \mathrm{~h}$ & $15 \mathrm{~min}$ & $24 \mathrm{~h}$ & $\mathrm{~L}$ & $\mathrm{a}$ & $\mathrm{b}$ \\
\hline \multirow{4}{*}{ Kh1 } & \multirow{2}{*}{ 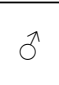 } & $\mathrm{x}$ & $6.28^{* a}$ & $6.14^{\mathrm{a}}$ & $6.36^{* a}$ & $6.28^{\mathrm{a}}$ & $46.90^{* a}$ & $16.84^{\mathrm{a}}$ & $6.07^{* a}$ \\
\hline & & SEM & 0.05 & 0.04 & 0.13 & 0.05 & 1.05 & 0.64 & 0.32 \\
\hline & \multirow[b]{2}{*}{ ㅇ } & $\mathrm{x}$ & $6.52^{\mathrm{a}}$ & $6.12^{\mathrm{a}}$ & $6.60^{\mathrm{a}}$ & $6.38^{\mathrm{a}}$ & $44.01^{\mathrm{a}}$ & $17.44^{\mathrm{a}}$ & $4.88^{\mathrm{a}}$ \\
\hline & & SEM & 0.08 & 0.05 & 0.04 & 0.07 & 0.99 & 0.12 & 0.39 \\
\hline \multirow{4}{*}{ P8 } & \multirow{2}{*}{$\hat{\sigma}$} & $\mathrm{x}$ & $6.19^{\mathrm{a}}$ & $5.84^{\mathrm{b}}$ & $6.34^{\mathrm{a}}$ & $6.15^{\mathrm{a}}$ & $44.69^{a}$ & $17.33^{\mathrm{a}}$ & $4.51^{\mathrm{b}}$ \\
\hline & & SEM & 0.05 & 0.03 & 0.04 & 0.05 & 0.65 & 0.33 & 0.27 \\
\hline & \multirow{2}{*}{ 우 } & $\mathrm{x}$ & $6.07^{b}$ & $5.90^{\mathrm{b}}$ & $6.27^{b}$ & $6.25^{\mathrm{a}}$ & $44.34^{\mathrm{a}}$ & $16.67^{\mathrm{a}}$ & $3.85^{\mathrm{b}}$ \\
\hline & & SEM & 0.03 & 0.03 & 0.03 & 0.02 & 0.78 & 0.28 & 0.24 \\
\hline
\end{tabular}

values in columns with asterisk $(*)$, compared between males and females in flock, differ significantly $(\mathrm{P} \leq 0.05)$ those bearing different letters $(\mathrm{a}, \mathrm{b})$ concern a comparison of flocks separately for each $\operatorname{sex}(\mathrm{P} \leq 0.05)$

Body weights of Kh1 males and females were significantly lower than in P8 birds. Dressing percentage of ducks in both flocks varied from $65.7 \%$ in $\mathrm{Kh} 1$ males to $70.5 \%$ in $\mathrm{P} 8$ females. Breast muscle percentage in Kh1 males was significantly $(\mathrm{P} \leq 0.05)$ lower than in $\mathrm{P} 8$ males. Females of both flocks were characterized by similar percentages of breast muscles, which ranged from $9.7 \%$ in $\mathrm{Kh} 1$ to $10.3 \%$ in P8. Carcasses of Kh1 compared to P8 birds were characterized by a higher percentage of leg muscles and lower percentages of skin with subcutaneous fat and abdominal fat.

$\mathrm{pH}_{15}$ and $\mathrm{pH}_{24}$ values determined in breast muscles in both flocks were lower than in leg muscles (Table 3 ). $\mathrm{pH}_{15}$ values of breast muscles ranged in males from 6.19 (P8) to 6.28 (Kh1), and in females from 6.07 (P8) to $6.52(\mathrm{Kh} 1) \cdot \mathrm{pH}_{24}$ values of breast muscles were lower than $\mathrm{pH}_{15}$ and ranged in males from 5.84 (P8) to 6.14 (Kh1) and in females from 5.90 (P8) to 6.12 (Kh1). With regard to leg muscles, a higher $\mathrm{pH}_{15}$ was characteristic of Kh1 drakes and ducks (6.36 and 6.60, respectively) and a lower $\mathrm{pH}_{15}$ was found in $\mathrm{P} 8$ ducks (from 6.27 in females to 6.34 in males). A similar relationship was revealed for $\mathrm{pH}_{24}$, because greater values were determined in leg muscles of Kh1 drakes and ducks (6.28 and 6.38) and lower values in P8 males and females (6.15 and 6.25, respectively). Similar colour of breast muscle (L) was characteristic of birds from both flocks, ranging from 46.90 in Kh1 males to 44.01 in Kh1 females, and from 44.69 in P8 males to 44.34 in P8 females (Table 3). In addition, breast muscles of the birds of both sexes from Kh1 flock were characterized by similar redness (a) and significantly greater yellowness (b) compared to muscles of P8 ducks. 
TABLE 4

Comparison of white $(\alpha \mathrm{W})$ and red fibre $(\beta \mathrm{R})$ diameters in Pectoralis superficialis and Biceps femoris muscles of 7-week-old female ducks from two conservative flocks

\begin{tabular}{|c|c|c|c|c|c|}
\hline \multirow[t]{2}{*}{ Flock } & & \multicolumn{2}{|c|}{$\begin{array}{l}\text { Pectoralis superficialis muscle } \\
\text { - muscle fibres, } \mu \mathrm{m}\end{array}$} & \multicolumn{2}{|c|}{$\begin{array}{l}\text { Biceps femoris muscle } \\
\text { - muscle fibres, } \mu \mathrm{m}\end{array}$} \\
\hline & & $\alpha \mathrm{W}$ & $\beta R$ & $\alpha \mathrm{W}$ & $\beta \mathrm{R}$ \\
\hline \multirow{2}{*}{ Kh1 } & $\mathrm{x}$ & $31.3^{\mathrm{a}}$ & $16.6^{\mathrm{a}}$ & $46.0^{\mathrm{b}}$ & $32.7^{\mathrm{a}}$ \\
\hline & SEM & 0.5 & 0.1 & 0.3 & 0.7 \\
\hline \multirow{2}{*}{ P8 } & $\mathrm{x}$ & $31.6^{\mathrm{a}}$ & $17.1^{\mathrm{a}}$ & $49.8^{\mathrm{a}}$ & $34.7^{\mathrm{a}}$ \\
\hline & SEM & 0.6 & 0.4 & 1.0 & 0.8 \\
\hline
\end{tabular}

values in columns marked with different letters differ significantly $(\mathrm{P} \leq 0.05)$

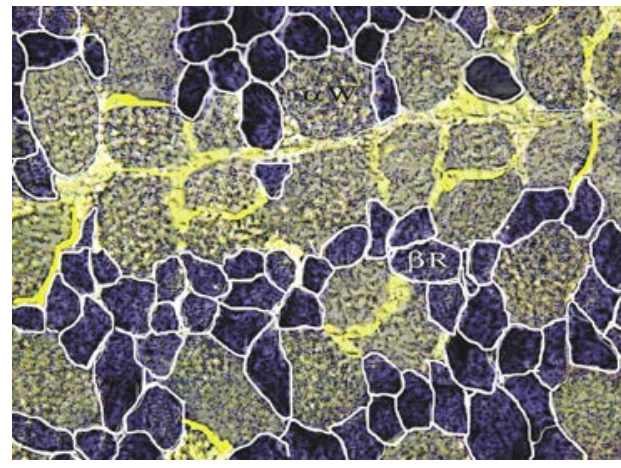

Figure 1. Cross-section of Pectoralis superficialis muscle in Kh1 female ducks

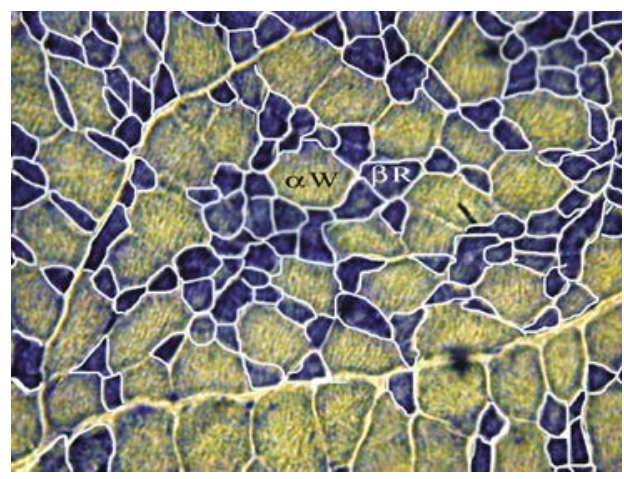

Figure 3. Cross-section of Pectoralis superficialis muscle in $\mathrm{P} 8$ female ducks

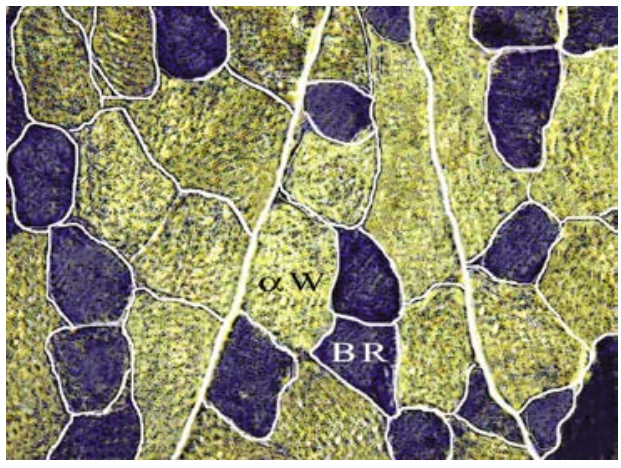

Figure 2. Cross-section of Biceps femoris muscle in Kh1 female ducks

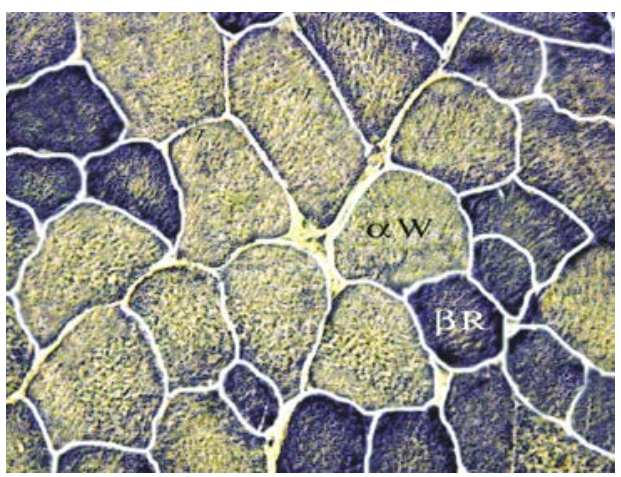

Figure 4. Cross-section of Biceps femoris muscle in P8 female ducks 
Based on analysis of the birds' muscle microstructure (Table 4, Figures 1-4), lower diameters were found for white $(\alpha \mathrm{W})$ and red muscle fibres $(\beta \mathrm{R})$ in Pectoralis superificialis than in Biceps femoris muscles. Muscle fibres of Kh1 compared to P8 ducks were characterized by lower diameters of $\alpha \mathrm{W}$ and $\beta \mathrm{R}$ fibres in Pectoralis superificialis and Biceps femoris muscles. However, statistical differences between the flocks were only found in the mean diameter of $\alpha \mathrm{W}$ fibres in Biceps femoris muscle.

\section{DISCUSSION}

The duck flocks being compared represented two different utility types, i.e. the light type (Kh1) and the multipurpose type (P8). Body weight of Khaki Campbell ducks at 7 weeks of age was similar in both sexes, and those of P8 ducks lower by $215 \mathrm{~g}$ than obtained earlier by Książkiewicz (1995) who, however used feed mixture of higher protein content and higher energy value (Table 1). Low body weights of 1661 to $1894 \mathrm{~g}$ at 8 weeks of age in local duck populations unselected for this trait were also reported by Iguzar et al. (2002). P8 ducks analysed in the present experiment were characterized by lower body weights compared to English ducks (Powell, 1986). These birds, unselected for increased feed conversion rate, were significantly lighter at 7 weeks of age compared to selected birds (Powell, 1986).

Dressing percentage of P8 ducks was greater than that obtained by Książkiewicz (1997) for the same population and greater than that of Pekin ducks from Hungary, Germany, Russia and the Czech Republic tested in Ivanka on the Danube (Evaluation, 1989). Staško (1990) reported that at 10 weeks in males and 8 weeks in females in the crosses of Khaki Campbell, wild mallard and Pekin ducks, dressing percentage reached up to $74 \%$ on average.

Meat quality traits evaluated from $\mathrm{pH}$ value of breast and leg muscles and meat colour were hitherto explored only in Pekin and Muscovy ducks (Smith et al., 1992; Baéza et al., 1998). The present findings indicate greater $\mathrm{pH}_{15}$ and $\mathrm{pH}_{24}$ values of breast and leg muscles in Khaki Campbell than in P8 Pekin ducks. The values of breast muscle colour were similar in both flocks. Smith et al. (1992) obtained in Pekin ducks a greater difference in $\mathrm{pH}$ value of breast muscle, from 6.25 at $25 \mathrm{~min}$ post mortem to 5.66 at $24 \mathrm{~h}$ post mortem. Similar $\mathrm{pH}$ values for breast muscle, ranging from 6.16 at $25 \mathrm{~min}$ to 5.64 at $24 \mathrm{~h}$ post mortem, were reported in hens by Kijowski et al. (1982). In poultry, more glycogen is found in breast than in leg muscles, which results in $\mathrm{pH}$ of breast muscles post mortem being lower than for leg muscles. Baéza et al. (1998) showed in Muscovy ducks the effect of age on decreased $\mathrm{pH}$ value of breast muscles. Muscles of 8-week-old ducks were characterized by $\mathrm{pH}$ values of 6.50 at $20 \mathrm{~min}$ post mortem and 6.17 after $24-\mathrm{h}$ chilling, but at 15 weeks of age $\mathrm{pH}$ values of the meat were lower (from 6.40 to 
5.89). This is considered unfavourable, possibly indicating a PSE-type meat defect (pale, soft, exudative).

Measurements of meat colour in both flocks of ducks were similar and gave no indication of meat defects. Breast muscles of ducks evaluated by Chen et al. (1991) had lower lightness $(\mathrm{L}=31.8)$ and redness values $(\mathrm{a}=13.4)$. These authors noted that stress and shyness of birds resulted in DFD meat (dark, firm, dry). Wołoszyn (2002) obtained in Pekin ducks $\times$ Muscovy drakes L values of about 45. Baéza et al. (1997) reported darker meat colour in heavy strains of Muscovy ducks $(\mathrm{L}=35.6)$; these ducks were also characterized by greater b (8.40) and lower a (9.98) values. Gianfaldoni et al. (1994) reported that 12-week-old Muscovy ducks also had darker meat colour ( $\mathrm{L}=38.2)$, but their meat showed greater redness $(\mathrm{a}=18.8)$ and yellowness $(b=6.3$ ) compared to the meat of birds studied by us. Based on the results of many experiments, the following factors influencing meat colour can be distinguished: species, sex, age, feeding system, muscle type, muscle $\mathrm{pH}$, muscle thickness, and contents of intramuscular fat and connective tissue in muscle (Renerre, 1999).

The present study confirmed the heterogeneous structure of Pectoralis superficialis and Biceps femoris muscles in the ducks. The small fibre size of meat from Kh1 and P8 flocks is technologically desirable.

The investigations of muscle fibres diameter carried out on coot (Fulica atra) have shown a greater diameter of muscle fibres (from 30.7 to $32.5 \mu \mathrm{m}$ ) in Pectoralis superficialis muscle, without differentiation into white and red fibres (Pakocińska et al., 1972). It should be metioned that coots, similarly as Khaki Campbell ducks, demonstrate low body weight and both population are included to light type of utility. In addition, the birds studied by Pakocińska at al. (1972) were flight birds, which could have influenced the greater diameter of muscle fibres. The present study showed that $\alpha \mathrm{W}$ and $\beta \mathrm{R}$ muscle fibre diameters were greater in Biceps femoris than in Pectoralis superficialis muscle. Biesiada-Drzazga et al. (2000), when exploring the effects of age and nutrition on muscle fibre thickness, reported a similar pattern in ducks from the Polish breeding strain A44. In 7-week-old ducks fed different feed mixtures, muscle fibre diameters ranged from 25.2 to $27.8 \mu \mathrm{m}$ in Pectoralis superficialis muscle and from 54.4 to $61.5 \mu \mathrm{m}$ in Biceps femoris muscle. In 8-week-old ducks, muscle fibre thickness increased in these muscles from 29.1 to $31.5 \mu \mathrm{m}$ and from 58.2 to $63.9 \mu \mathrm{m}$, respectively. Furthermore, the same authors showed a relationship between duck nutrition and muscle fibre thickness. In birds fed a mixture with yellow lupin meal, they found lower diameter of fibres in Biceps femoris muscle compared to birds fed with a soyabean meal diets.

\section{CONCLUSIONS}

Ducks from Khaki Campbell (Kh1) and Pekin (P8) conservative flocks are characterized by high biodiversity in aspect of meat traits. The experiment showed 
that the meat of ducks from the investigated flocks has a high value from the consumer's point of view. These ducks can be utilized both in breeding program and an ecological maintenance.

\section{REFERENCES}

Ashmore C.R., Doerr L., 1971. Comparative aspects of muscle fiber types in different species. Exp. Neurol. 31, 408-418

Baéza E., De Carville H., Salichon M.R., Marche G., Leclercq B., 1997. Effects of selection, over three and four generations, on meat yield and fatness in Muscovy ducks. Brit. Poultry Sci. 38, 359-365

Baéza E., Salichon M.R., Marche G., Juin H.,1998. Effect of sex on growth, technological and organoleptic characteristics of the Muscovy duck breast muscle. Brit. Poultry Sci. 39, 398-403

Biesiada-Drzazga B., Górski J., Witak B., 2000. Effects of feeding and age on thickness of muscle fibre in meat ducks of the A44 breed. In: Proceedings of $21^{\text {st }}$ World's Poultry Congress, Montreal, CD ROM

Brooke M.H., 1970. Some comments on neural influence on the two histochemical types of muscle fibers. Physiol. Biochem. Muscle Food 2, 131-153

Chen Ming-Tsao, Sun-San L., Liang Chuan L., 1991. Effect of stresses before slaughter on changes to the physiological, biochemical, and physical characteristics of the duck muscle. Brit. Poultry Sci. 32, 997-1004

Dubowitz V., Brooke M.H., Neville H. E., 1973. Muscle Biopsy. A Modern Approach. W. B. Saunders (Editor). Company Ltd., London

Evaluation of $20^{\text {th }}$ Test in Rearing of Ducks (in Czech), 1989. International Station of Control and Research on Poultry, Ivanka on the Danube

Fujihara N., Xi Y.M., 1999. Genetic resource conservation in the waterfowl. In: Proceedings of $1^{\text {st }}$ World Waterfowl Conference, Taiwan (ROC), pp. 63 -69

Gianfaldoni D., Campodoni G., Giuliotti L., Preziuso G., Sacchi P., Turi R.M., Romboli I., 1994. B-Agonists in muscovy drakes: Meat characteristics and residues in some organs and tissues. In: Proceedings of $9^{\text {th }}$ European Poultry Conference, Glasgow, pp. 215-216

Iguzar E., Kocak C., Pingel H., 2002. Growth, carcass traits and meat quality of different local ducks and Turkish Pekins. Arch. Tierzucht 45, 1-6

Kijowski J., Niewiarowicz A., Kujawska-Biernat B., 1982. Biochemical and technological characteristics of hot chicken meat. J. Food Technol. 17, 553-560

Kłosowska D., Bernacki Z., 1999. Changes in muscle fiber diameter and muscle fiber composition in pectoralis muscle of duck from two genetic groups during postnatal growth. Bydgoszcz Scientific Society, Ser. B, 45, 137-143

Kobus P., Pietrzykowski R., Zieliński W., 2001. Statistica with STATISTICA Program (in Polish). SGGW Warszawa, 7-100

Książkiewicz J., 1995. Duck gene pool. In: Proceedings of International Symposium on Conservation Measures for Rare Farm Animal Breeds. Balice (Poland), pp. 289-292

Książkiewicz J., 1997. Characteristics of meatness traits in six generations of ducks in conservative groups. J. Anim. Feed Sci. 6, 101-108

Książkiewicz J., 2002. Reproductive and meat characteristics of Polish ducks threatened with extinction. Czech J. Anim. Sci. 47, 401-410

Książkiewicz J., 2003. Comparison of reproduction and meatiness traits in light type of ducks of four conservative flocks over eight generations. Arch. Tierzucht 46, 377-389 
Książkiewicz J., Kiełczewski K., 1998. Time trends of reproductive traits in the conservative groups of pekin type ducks over eight generations. Rocz. Nauk. Zoot. 25 (4), 85-95

Książkiewicz J., Smalec E., Grużewska A., 1997. Model of duck growth. In: Proceedings of $11^{\text {th }}$ European Symposium on Waterfowl, Nantes, pp. 605-610

Książkiewicz J., Stępińska M., Niemiec J., 1999. Differences in the morphological traits and yolk lipids composition of eggs from selected conservative groups of ducks. In: Proceedings of $8^{\text {th }}$ European Symposium on the Quality of Eggs and Egg Products, Bologna, pp. 71-75

Pakocińska J., Smolińska T., Górska I., 1972. Technological characteristics of mallard duck (Anas platyrhynchos) and coot (Fulica atra) carcasses and meat (in Polish). Zesz. Nauk. WSR Wrocław 97, Zoot. 18, 131-140

Powell J.C., 1986. The possibilities for genetics improvement of commercial production characteristics and carcass quality in the meat duck. In: D.J. Farrell, P. Stapleton (Editors). Duck Production Science and World Practice. Univ. New England, Armidale, pp. 184-192

Poland's Country Report on Farm Animal Genetics Resources (in Polish), 2002. Research Institute of Animal Production, National Animal Breeding Centre, Warsaw, pp. 3-99

Renerre M., 1999. Biochemical basis of fresh meat colour. In: Proceedings of $45^{\text {th }}$ International Congress of Meat Science and Technology, Yokohama, pp. 344-351

Smith D.P., Fletcher D.L., Papa C.M., 1992. Post-mortem biochemistry of pekin duckling and broiler chicken pectoralis muscle. Poultry Sci. 71, 1768-1772

Staško J., 1990. Variation in parameters at the duck breeding. In: Proceedings of $8^{\text {th }}$ Poultry Conference, Barcelona, pp. 497-500

Wołoszyn J., 2002. The physicochemical and technological characteristic of muscles from force fed duck (in Polish). Thesis, Economical Academy, Wrocław (Poland), pp. 5-136

Wołoszyn J., Książkiewicz J., Orkusz A., Skrabka-Błotnicka T., Biernat T., Kisiel T., 2002. Preliminary evaluation of chemical composition of duck muscles from two Polish conservative flocks. In: Proceedings of $48^{\text {th }}$ International Congress of Meat Science and Technology, Rome, pp. 374-375

\section{STRESZCZENIE}

\section{Cechy fizyczne i jakościowe mięsa kaczek z dwóch stad zachowawczych}

W stadach zachowawczych kaczek Khaki Campbell (Kh1) i Pekin (P8) określono procentową zawartość w tuszce patroszonej: mięśni piersiowych, nóg, skóry z tłuszczem podskórnym i thuszczu sadełkowego oraz wartości cech jakościowych mięsa : $\mathrm{pH}_{15}, \mathrm{pH}_{24} \mathrm{i}$ barwę oraz właściwości histologiczne mięsa. W badanych stadach stwierdzono istotne statystycznie różnice w masie ciała $\mathrm{w} 7$. tygodniu życia (kolejno u Kh1 i P8 1383 i 2292 g u samców oraz 1396 i 2177 g u samic).

Wartości $\mathrm{pH}_{15}$ mięśni piersiowych i nóg ptaków Kh1 i P8 były większe niż $\mathrm{pH}_{24}$ w tych mięśniach. W obydwóch stadach stwierdzono mniejsze wartości $\mathrm{pH}_{15}$ w mięśniach piersiowych, od 6,07 do 6,52 i $\mathrm{pH}_{24}$ od 5,84 do 6,14, w porównaniu z mięśniami nóg, odpowiednio od 6,27 do 6,60 i od 6,15 do 6,38 . Barwa mięśnia piersiowego (L) była zbliżona u ptaków z obydwóch stad, przyjmując wartości od 46,90 u samców Kh1 do 44,01 u samic, a w P8 odpowiednio 44,69 i 44,34. Mięśnie piersiowe ptaków obojga płci ze stada Kh1 odznaczały się istotnie większym wysyceniem barwy żółtej (b) w porównaniu z mięśniami kaczek P8. W mięśniach piersiowych powierzchownych obydwóch stad stwierdzono mniejszą średnicę włókien mięśniowych białych $(\alpha \mathrm{W})$ i czerwonych $(\beta R)$ niż w mięśniach dwugłowych uda. Włókna mięśniowe kaczek Kh1 w porównaniu z P8 miały mniejszą średnicę włókien $\beta \mathrm{R}$ i $\alpha \mathrm{W}$ w mięśniu piersiowym powierzchownym i dwugłowym uda (31,3 i 16,6 oraz 46,0 i 32,7 $\mu \mathrm{m}$, odpowiednio). 